\title{
Daily treatment with sildenafil, an inhibitor of cGMP-dependent phosphodiesterase, normalizes the exaggerated hemodynamic response to norepinephrine in fructose-fed rats Delphine Behr-Roussel ${ }^{* 1}$, Alexandra Oudot ${ }^{1}$, Sandrine Compagnie ${ }^{1}$, Diana Gorny ${ }^{1}$, Olivier Le Coz ${ }^{1}$, Jaques Bernabé ${ }^{1}$, Chris Wayman², Laurent Alexandre ${ }^{1}$ and Francois Giuliano ${ }^{3}$
} \author{
Rehabilitation, AP-HP Raymond Poincaré hospital, Garches, France \\ Email: Delphine Behr-Roussel* - d.behr.roussel@pelvipharm.com \\ * Corresponding author

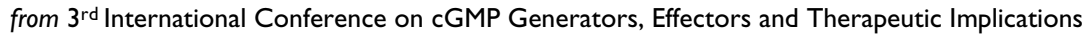 \\ Dresden, Germany. 15-17 June 2007 \\ Published: 25 July 2007 \\ BMC Pharmacology 2007, 7(Suppl I):P5 doi:10.1 I86/I47I-2210-7-SI-P5
}

Address: ${ }^{1}$ Pelvipharm, Gif-sur-Yvette, France, ${ }^{2}$ Pfizer Global Research and Development, Sandwich, Kent, UK and ${ }^{3}$ Department of Neurological

This abstract is available from: http://www.biomedcentral.com/I47I-22I 0/7/SI/P5

(c) 2007 Behr-Roussel et al; licensee BioMed Central Ltd.

\section{Background}

Enhanced responsiveness of the vascular smooth muscle cell to vasoconstrictor stimuli has been described in insulin-resistant states. Fructose overload leads to the development of the metabolic syndrome and its associated cardiovascular disorders including hypertension. We postulated that chronic treatment with sildenafil would regulate the abnormally increased pressor response to a norepinephrine challenge in fructose-fed rats. Material and methods Wistar rats were fed a standard chow (CONT, $\mathrm{n}=12$ ) or a $60 \%$ fructose-enriched diet containing $5 \%$ fat ( $\%$ by weight) for 8 weeks (FFR, $n=12$ ). From week 5 through 8 , sildenafil (twice a day sc, $20 \mathrm{mg} / \mathrm{kg}$ ) was administered (FFR+SIL, $\mathrm{n}=14$ ), thus reaching clinically relevant plasma concentrations circa $20 \mathrm{nM}$ unbound (Pfizer Inc., data on file), followed by a 1-week wash-out period (W9). On W9, in a sub-group of these conscious rats $(n=5)$ that had previously been implanted with telemetric devices, AP was recorded following cumulative infusion of noradrenaline (NA 50, 100, 200, 400 $\mathrm{ng} / \mathrm{kg} / \mathrm{min}$ ). In all rats, urinary 8-isoprostane (IPT) and TxB2 levels were determined during a 24 -hour period. Tissue ET-1 content was measured in segments of aortic and mesenteric artery.

\section{Results}

Fasting glycemia was unchanged in all rats while triglyceridemia were elevated in FFR compared to CONT $(2.0 \pm 0.4$ $\mathrm{mM}$ vs $1.2 \pm 0.2, \mathrm{p}<0.05)$ and corrected by sildenafil treatment $(1.3 \pm 0.2$, NS vs CONT). Resting AP was similar in all rats. Pressor responses to NA were exacerbated in FFR (maximal increase from basal MAP: $+22.8 \pm 1.7$ vs $+38.0 \pm 7.3 \mathrm{mmHg}$, respectively, $\mathrm{p}<0.05)$ and normalized by sildenafil treatment $(+24.9 \pm 5.2 \mathrm{mmHg}$, NS vs CONT). Vascular ET-1 levels were not modified by the fructose nor sildenafil treatment whereas the increased production of urinary IPT and TxB2 in FFR versus CONT $(2.07 \pm 0.36 \mathrm{ng} / \mathrm{ml} / 24 \mathrm{~h}$ vs $0.88 \pm 0.13$ and $12.86 \pm 1.91$ $\mathrm{pg} / \mathrm{ml} / 24 \mathrm{~h}$ vs $7.25 \pm 0.59$, respectively, $\mathrm{p}<0.05)$ were corrected following sildenafil treatment $(0.95 \pm 0.14 \mathrm{ng} /$ $\mathrm{ml} / 24 \mathrm{~h}$ and $8.74 \pm 1.06 \mathrm{pg} / \mathrm{ml} / 24 \mathrm{~h}$, respectively, NS vs CONT).

\section{Conclusion}

In FFR, pressor responses to NA were potentiated, suggesting enhanced responsiveness of the vascular smooth muscle cell to vasoconstrictor stimuli. Chronic treatment with sildenafil was able to normalize the hemodynamic response to norepinephrine while restoring normal excretion of urinary biological markers of oxidative stress and 
vasoactive mediators in FFR. Both IPT and TxB2 could be considered as surrogate markers of endothelial function in clinical trials addressing cardiovascular risks.

\section{Acknowledgements}

This study was supported by an independent investigator research grant from Pfizer.

Publish with Biomed Central and every scientist can read your work free of charge

"BioMed Central will be the most significant development for disseminating the results of biomedical research in our lifetime." Sir Paul Nurse, Cancer Research UK

Your research papers will be:

- available free of charge to the entire biomedical community

- peer reviewed and published immediately upon acceptance

- cited in PubMed and archived on PubMed Central

- yours - you keep the copyright 